\title{
Todd Walatka
}

Von Balthasar and the Option for the Poor: Theodramatics in the Light of

Liberation Theology. Washington, DC: Catholic University of America Press, 2017.

Pp. xii + 249. Hb, \$69.95.

One must not underestimate the significance of this book. At first glance, one might slot it as a welcome contribution to the secondary literature on Hans Urs von Balthasar focused on one small aspect of his theology, namely his treatment of liberation theology and the poor. Certainly the book is this. But it is much more. In the age of Pope Francis, this study captures his spirit. It refuses any false dichotomy that would divide the Catholic Church by isolating obedient surrender to the revealed glory of the triune God from the evangelical work of social justice and social transformation. For Pope Francis and for Walatka, these two-doxology and liberation-must be understood and practiced together. Pope Francis and Walatka both argue persuasively that bearing witness to Christ by participating in his salvific mission cannot be reduced to - but must still necessarily incorporate and demand — active solidarity with "the least of these," in the midst of a world that sinfully oppresses and ignores them. This is not merely an extraordinarily lucid and helpful analysis of von Balthasar. It is a vision for what Catholic theology can be if it takes seriously all dimensions of the Second Vatican Council's call to holiness.

Scholars dedicated to the interpretation of von Balthasar and scholars engaged in the ongoing development of liberation theology will both find much to appreciate in this book. Balthasarians will be especially pleased that this is a generous and charitable reading, which gives von Balthasar as much credit as possible. Walatka's tone is never dismissive. Rather it is searching. He highlights several respects, often overlooked by proponents and critics of von Balthasar alike, in which his thought already aligns with the goals of liberation theology. For example, Walatka points to von Balthasar's Ignatian affirmation of the unity of contemplation and action, his recognition that participating in the mission of Christ requires active involvement in the historical world, and his articulation of a firm Christian duty to serve the poor. Moreover, Walatka grants that some of von Balthasar's explicit concerns about liberation theology, particularly concerns that the apocalyptic vision of Christian salvation will be reduced to utopian projects of historical liberation, may be somewhat justified, especially in the cases of certain more secularly minded liberation theologians such as Juan Luis Segundo. Finally, when Walatka does push back against von Balthasar, he does so largely by employing a method of immanent critique. He argues that the same sort of plural, symphonic, truth-seeking hermeneutic that von Balthasar used to retrieve certain questionable figures of the Christian 
tradition, such as Origen and Eckhart, ought to have been extended to contemporary liberation theologians as well. In all of these respects, Walatka's volume will make Balthasarians happy. It is not a polemic against von Balthasar but rather a thoughtful extension of his theodramatic vision.

Advocates of liberation theology who are accustomed to seeing von Balthasar as an adversary may at first be tempted to object to Walatka's very decision to offer such a charitable reading of von Balthasar. They may worry that this move will contribute to the academic watering down of liberation theology lamented by critics such as Ivan Petrella. However, Walatka's sympathetic interpretations of Jon Sobrino and Gustavo Gutiérrez, his passionate demand that Christian theology enact a preferential option for the poor, and above all his celebration of Oscar Romero as a powerful icon of theodramatic action and Christian witness may rightly allay these doubts and earn Walatka the approval of many (if not all) liberation theologians. The argument of this text is not so much that liberation theology needs a Balthasarian corrective. The argument is more nearly the reverse, namely that Balthasarian theology needs liberation theology in order to make good on its own theodramatic principles. Provided that liberation theologians are serious about avoiding historical reductionism, as Walatka shows that some prominent figures such as Sobrino and Gutiérrez are, then there is little in this book to which they might reasonably object. Walatka is a true ally.

Some readers, and I am among them, may be especially grateful for Walatka's attention to the problem of racism. While arguing that the theodramatic battle between sin and grace needs to incorporate a structural account of sin, Walatka turns to the example of "racial injustice against black Americans by means of slavery, Jim Crow laws, redlining housing policies, explicit racism, cultural bias, and the criminal justice system" (158). This aspect of Walatka's argument shows that it may have relevance, not only for those interested in Latin American liberation theology, but also for liberation theologians in the United States, including black liberation theologians. Although Walatka does not offer an extensive treatment of sexism in this book, he does provide one lengthy footnote $(76 \mathrm{n} 104)$ which points to critical studies of von Balthasar's views on gender and acknowledges the legitimacy of feminist critiques of his gender essentialism.

I would highly recommend this book for use in any course that covers von Balthasar's theology or liberation theology_and especially if it covers both. The writing is crystal clear. The argument occurs at a level that advanced undergraduate students and graduate students of all levels will be able to understand. I can personally attest that several students in my graduate von Balthasar seminar found it immensely helpful. At the same time, it sets a new standard 
for scholarship on von Balthasar and liberation theology, which ought to propel research forward in new directions. It is poised to contribute to both teaching and thought. Yet, as I indicated at the outset, its significance is greater still. It represents the inseparably doxological and liberative practice of Christian life and reflection which the twenty-first Catholic Church desperately needs.

Andrew Prevot

Boston College

prevota@bc.edu

DOI 10.1163/22141332-00502005-17 